\title{
Ekspansi Bisnis Pergudangan Dusun Patte'ne Desa Temmapadduae Kabupaten Maros, 1995-2017
}

\author{
Mariana ${ }^{1}$, Muh Rasyid Ridha ${ }^{2}$ Jumadi $^{3}$ \\ 'Prodi Pendidikan Sejarah Fakultas Ilmu Sosial UNM \\ 'marianahabra.127@gmail.com, ${ }^{2}$ rasyidridha@unm.ac.id
}

\begin{abstract}
Abstrak
Penelitian ini bertujuan untuk mengetahui latar belakang terbentuknya pergudangan di Dusun Patte'ne Desa Temmapadduae Kabupaten Maros, perkembangan Pergudangan serta dampaknya terhadap masyarakat di kabupaten Maros. Hasil penelitian ini menunjukan bahwa latar belakang terbentuknya Gudang di Patte'ne dikarenakan letak geografis yang dekat dengan pusat kota dan kepadatan penduduk kota serta banyaknya lahan kosong untuk pembangunan gudang dan banyaknya bahan baku dari luar yang membutuhkan tempat penyimpanan. Kehadiran pergudangan bagi pemerintah memberikan keuntungan terhadap Pajak serta membantu Pemerintah Setempat untuk mengurangi Pengangguran. Kemudian bagi masyarakat membantu dalam hal peningkatan kualitas peluang usaha yang dulunya hanya mendirikan warung-warung kecil kini menjadi cukup besar. Masyarakat juga terbantu dalam hal menunaikan ibadah haji dan umrah dari penjualan lahan mereka. Ratusan orang telah menunaikan haji dan umrah karena dari penjualan tersebut. Penelitian ini adalah penelitian sejarah dengan metodologi sejarah yang memiliki tahap yaitu, heuristik (pengumpulan data), kritik (verifikasi), interpretasi (penafsiran), dan historiografi (penulisan sejarah).
\end{abstract}

Kata Kunci:Perkembangan, Pergudangan dan Desa Patte'ne

\begin{abstract}
This research aims to find out the background of warehousing formation in the village of Patte'ne Temmapadduae, Maros Regency, development of warehouse and its impact on people in Maros district. The results of this study showed that the background was formed by the warehouse in Patte'ne because of the geographical location that is close to the city center and city population density as well as the number of vacant land for warehouse development and many raw materials from outside Requiring a storage space. The presence of warehousing for the government provides benefits to taxes and helps the local government to reduce unemployment. Then for the community to help in terms of improving the quality of business opportunities that used to only set up small stalls now become large enough. People are also helped in doing Hajj and Umrah from the sale of their land. Hundreds of people have performed Hajj and Umrah because of the sale. This research is a historical study with historical methodologies that have the stage that is, heuristics (data collection), criticism (verification), interpretation (interpretation), and historiography (historical writing).
\end{abstract}

Keywords: Developments, Warehousing and Patte'ne Village.

\section{A. Pendahuluan}

Perkembangan perusahaan saat ini berkembang dengan cepat. Memasuki globalisasi, persaingan usaha semakin ketat, ini dikarenakan masuknya era pasar bebas yang menuntut perusahaan untuk dapat berkompetitif dengan baik dan lebih kreatif agar dapat bertahan dalam dunia usaha. Kondisi tersebut menuntut perusahaan untuk selalu mengembangkan strategi perusahaan agar dapat bertahan, berdaya saing dan terus berkembang ditengah gencarnya persaingan usaha.
Salah satu usaha untuk menjadi perusahaan yang besar dan kuat adalah melalui perluasan usaha atau ekspansi. Ekspansi Bisnis umumnya dipandang sebagai salah satu indikator keberhasilan atau kemajuan sebagai sebuah perusahaan atau anak perusahaan. Profit mendorong seorang berbisnis dan melakukan ekspansi atas bisnisnya (melakukan perluasan usaha). (Anita, 2015)

Salah satu kawasan ekspansi bisnis yang berkembang terus menerus sampai sekarang dan bergerak dalam ekspansi pergudangan yang sampai sekarang menjadi kawasan industri pergudangan terbesar di Sulawesi Selatan 
adalah bisnis pergudangan yang berada di Kawasan Pattene Business Park, Dusun Pattene Desa Temmapadduae Kabupaten Maros, Sulawesi Selatan.

Berkembangnya Dusun Pattene sebagai kawasan industri dalam hakikatnya tidak dapat dipisahkan dari kontribusi perusahaan swasta yang terus membangun pergudangan yang kemudian diperjualbelikan kepada masyarakat yang memiliki keinginan dan kemampuan untuk membangun usahanya sendiri dalam bidang pergudangan.

Pada awalnya pergudangan ini digunakan sebagai tempat menyimpan hasil produksi industri dan yang telah diolah oleh pabrik yang ada di Sulawesi Selatan yang kemudian berkembang menjadi pergudangan yang memproduksi industri yang kemudian dipasarkan di Wilayah Sulawesi Selatan Indonesia, bahkan beberapa hasil produksi pergudangan di Dusun Patte'ne ini disalurkan hingga keluar Pulau Sulawesi.

Kawasan Pergudangan yang ada di Dusun Pattene ini tidak muncul langsung berkembang pesat seperti yang dilihat sekarang, karena kawasan ini pada awalnya hanya didirikan satu pergudangan dan karena potensi yang dilihat oleh masyarakat setempat yang Dusun Patte'ne Desa Temmapadduae sebagai daerah yang dekat dengan perkotaan dan strategis dalam penyaluran barang hasil produksi sehingga tahun ketahun jumlah gudang di kawasan ini bertambah dan terus berkembang hingga sekarang.

Penelitian tentang bisnis pergudangan di Dusun Patte'ne Desa Temmapadduae Kabupaten Maros yang akan penulis kaji lebih dalam akan menjelaskan tentang bagaimana bisnis perusahaan tidak hanya berkembang di Kota besar atau daerah perkotaan yang padat penduduknya, tetapi membahas bagaimana Kabupaten Maros awalnya dipilih menjadi kawasan pergudangan yang hingga saat ini dapat menyerap ratusan pekerja dan berkembang menjadi kawasan bisnis. (Sumawi, 2019)

Penelitian ini juga akan menjelaskan bagaimana sejarah pergudangan yang awalnya hanya di pergunakan sebagai tempat penerimaan dan sampai pengirimannya kembali barang yang sejenak disimpan di dalam gudang tersebut sebagaimana pengertian gudang yang telah di jelaskan sebelumnya menjadi kawasan yang berkembang pesat dan menjadi tempat mengolah bahan baku menjadi barang jadi yang kemudian didistribusikan ke konsumen di wilayah Sulawesi Selatan, Indonesia bahkan sampai menjadi komuditi Export. (Aras, 2018)

Perbedaan bisinis pergudangan di Dusun Patte'ne di Desa Temmapadduae Kabupaten Maros dengan kawasan bisnis pergudangan lain yang ada di Sulawesi Selatan adalah dimana beberapa pergudangan tidak hanya menjalankan bisnis menerima barang hasil produksi dari pabrik ataupun perusahaan industri sampai pengiriman barang hasil produksi tersebut, tetapi mulai berkembang menjadi kawasan pergudangan bahan baku menjadi suatu produk barang jadi.

\section{B. Metode Penelitian}

Penelitian, banyak cara yang dilakukan oleh para peneliti baik berdasarkan proses, prosedur, maupun prisip yang dianut. (Ahmadin., 2013) Dengan demikian, berdasarkan atas tujuan dan kategori data yang dibutuhkan, menyebabkan terjadinya perbedaan metode yang diterapkan dalam kegiatan penelitian, beberapa metode yang umum digunakan dalam penelitian, salah satunya yaitu penelitian sejarah.

\section{Heuristik}

Tahap ini merupakan tahap mengumpulkan sumber-sumber sejarah yang relevan dengan topik penelitian. Kegiatan diarahkan pada pencarian dan pengumpulan sumber yang berkaitan dengan masalah atau objek yang akan dikaji, yaitu "bisnis pergudangan di Desa Temmapadduae Kabupaten Maros 1995-2017”. Proses mengumpulkan sumber dalam mengkaji dan menyusun penelitian ini menekankan pada kajian pustaka/library research dan wawancara. Wawancara dilakukan dengan kepala Dusun Patte'ne di Desa Temmapadduae, Pemilikpemilik gudang, dan masyarakat sekitar pergudangan.

\section{Kritik}

Setelah memperoleh sumber-sumber yang cukup memadai, selanjutnya dilakukan kritik (penyaringan) terhadap sumber tersebut. Kritik terhadap sumber bertujuan untuk memperoleh fakta-fakta yang seobyektif mungkin, sehingga karya sejarah yang dihasilkan merupakan produk dari proses ilmiah yang dapat dipertanggungjawabkan, bukan hasil dari suatu fantasi maupun manipulasi. (Sjamsuddin, 2012) 3. Interpretasi

Tahapan selanjutnya setelah proses kritik adalah penginterpretasian. Pada tahap 
interpretasi ini, subyektivitas seorang peneliti akan mulai tampak. Sejarah sangatlah penting dalam menguraikan masa lampau dengan dan dalam pembinaan karakter bangsa sehingga kita dibutuhkan melakukan interpretasi yang sesuai dengan data dilapangan. (Amirullah, A. (2017. Hal ini dapat dipahami karena pada tahap ini imajinasi dibutuhkan untuk menafsirkan seluruh kejadian berdasarkan fakta-fakta sejarah yang telah diperoleh pada tahapan sebelumnya. Terlepas dari hal demikian, peneliti harus bersifat obyektif agar karya yang diperoleh nantinya merupakan karya sejarah yang berkualitas. Fakta-fakta sejarah harus di interpretasikan atau ditafsirkan agar sesuatu peristiwa dapat direkonstruksikan dengan baik, yakni dengan jalan menyeleksi, menyusun, mengurangi tekanan, dan menempatkan fakta dalam urutan kausal. (Madjid, 2008)

\section{Historiografi}

Tahap ini merupakan tahap akhir dari metode sejarah. Pada tahap ini sejarawan mengerahkan seluruh daya pikirannya, bukan saja keterampilan teknis penggunaan kutipan dan catatan-catatan, yang paling utama yakni penggunaan pikiran-pikiran kritis dan analisanya karena sejarawan pada akhirnya harus menghasilkan sintesis dari seluruh hasil penelitiannya atau penemuannya itu dalam suatu penulisan utuh.

\section{Tinjauan Penelitian}

Sebelumnya telah ada penulis yang mengkaji mengenai bisnis Pergudangan dan Penulis menggunakannya sebagai tinjauan penelitian sebagai sebelumnya guna mempermudah proses pengumpulan data, diantaranya sebagai berikut:

Skripsi ini membahas mengenai eksistensi badan usaha untuk tetap bertahan dalam dunia bisnis untuk itu Koperasi UIN yang berusaha terus menerus mengembangkan usahanya, dalam skripsi ini juga di jelaskan bagaimana pengembangan koperasi UIN tidak terlepas dari upaya pengurus koperasi yang terus menerus berusaha meningkatkan daya saing dalam rangka melebarkan sayap dengan meningkatkan efisiensi dan efektivitas. (Reza, 2010)

Jurnal yang berjudul mengukur kekuatan ekspansi bisnis PT. Antan Ditinjau dari aspek kinerja keuangan yang di tulis oleh Yurasti SE. Msi, e-jurnal apresiasi Ekonomi Volume 1, Nomor 3, September 2013: 157-166. (Yurasti, 2013)Jurnal ini membahas tentang kekuatan
PT. ANTAM untuk terus melakukan ekpansi bisnis secara berkesinambungan menggarap potensi kekayaan tambang indonesia bahkan mengembangkan usaha keluar negeri sebagai perusahaan bertaraf global.

\section{Hasil dan Pembahasan}

\section{Perkembangan Pergudangan Dusun Patte'ne Desa Temmapadduae Kabupaten Maros Tahun 1995-2017}

Gudang merupakan bagian penting dari supply chain management. Akurasi stock, order picking system, pengisian kembali stock yang berkurang, layout merupakan kunci penting dalam meningkatkan kecepatan pelayanan. Untuk mencapai hal tersebut diantaranya dibutuhkan kemampuan untuk mengelola gudang dan manajemen persediaan. Pelatihan ini akan membantu peserta dalam memahami fungsi dari gudang dan persediaan serta pengaruhnya dalam meningkatkan efisiensi operasi. (Akhmad., 2006)

Gudang adalah fasilitas khusus yang bersifat tetap, yang dirancang untuk mencapai target tingkat pelayanan dengan total biaya yang paling rendah. Gudang dibutuhkan dalam proses koordinasi penyaluran barang, yang muncul sebagai akibat kurang seimbangnya proses penawaran dan permintaan. Kurang seimbangnya antara proses permintaan dan penawaran mendorong munculnya persediaan (inventory), persediaan membutuhkan ruang sebagai tempat penyimpanan sementara yang disebut sebagai gudang.

Tujuan dari adanya tempat penyimpanan dan fungsi dari pergudangan secara umum adalah memaksimalkan pengunaan sumbersumber yang ada disamping memaksimalkan pelayanan terhadap pelanggan dengan sumber yang terbatas. Sumber daya gudang dan pergudangan adalah ruangan, peralatan dan personil. Pelanggan membutuhkan gudang dan fungsi pergudangan untuk dapat memperoleh barang yang diinginkan secara tepat dan dalam kondisi yang baik. Maka dalam perancangan gudang dan system pergudangan diperlukan untuk hal-hal berikut ini: (Pornomo, 2004)

a. Memaksimalkan penggunaan ruang.

b. Memaksimalkan menggunakan peralatan.

c. Memaksimalkan penggunaan tenaga kerja.

Proses penahanan barang tersebut dilakukan disatu tempat yang berupa gudang. Jadi gudang atau storage merupakan tempat untuk menyimpan barang baik bahan baku, 
barang setengah jadi maupun barang jadi yang siap dikirim kepelanggan. Sebagian besar gudang yang digunakan untuk menyimpan barang ditempatkan pada lokasi tertentu sampai barang tadi diperlukan di dalam proses produksi. Bentuk gudang akan tergantung ukuran dan kuantitas dari komponen didalam persediaan dan karakter sistem penanganan.

Penyimpanan didalam gudang barang jadi bisa mencapai waktu yang cukup lama itu berdasarkan kebutuhan barang itu sendiri, sehingga ada beberapa macam tipe penyimpanan di dalam gudang yaitu dari macam-macam produk, produk yang mungkin tingkat umurnya pendek hanya menyimpan dalam skala waktu beberapa lama, akan tetapi produk yang umur produknya lama bisa menyimpan dalam waktu yang cukup lama, sehingga perlu membutuhkan tempat penyimpanan atau (storage)

Perkembangan perusahaan saat ini berkembang dengan cepat. Memasuki globalisasi, persaingan usaha semakin ketat, ini di karenakan masuknya era pasar bebas yang menuntut perusahaan untuk dapat berkompetitif dengan baik dan lebih kreatif agar dapat bertahan dalam dunia usaha. Kondisi tersebut menuntut perusaahan untuk selalu mengembangkan strategi perusahaan agar dapat bertahan, berdaya saing dan terus berkembang ditengah gencarnya persaingan usaha.

\section{Perkembangan Pergudangan Dusun Patte'ne Desa Temmapadduae Kabupaten Maros 1995-1998}

Dalam sejarahnya, Pada awalnya pergudangan diperlukan oleh industri pertanian akibat dari hasil yang melimpah pada saat panen, tetapi akan berkurang pada saat musim tanam. Hasil panen yang melimpah sebagian akan disimpan dalam tempat khusus (disebut dengan lumbung) dan sebagian di kelola untuk kebutuhan sehari-hari. Secara bertahap akan dikeluarkan dari lumbung sesuai periode berjalan, sampai tiba masa panen sebagai pasokan berikutnya kedalam lumbung tersebut. Dalam penyimpanan diperlukan tempat yang tidak menimbulkan kerusakan bagi produk dan aman terhadap kehilangan serta dapat diketahui jumlah didalamnya. Disamping itu diperlukan metode pengeluaran dengan cara pertama disimpan pertama dikeluarkan, agar hasil pertanian yang ada dalam lumbung tetap dalam kondisi baik (tidak rusak) dan dapat di pergunakan pada waktunya atau tidak kekurangan. Hal ini menjadi acuan penerapan manajemen yang diperlukan dalam pergudangan yang di kelolah secara baik, sehingga fungsi pergudangan secara garis besar adalah Penerimaan, penyimpanan, perawatan dan distribusi. Gudang juga berperan dalam pendistribusian barang untuk menjamin penyediaan produk yang baik untuk pelanggan pada periode waktu yang akan datang (future) merupakan penilaian terhadap utilitas gudang. (Syarifuddin, 2017)

Pada awalnya pendiri pertama pergudangan yang berada di Dusun Patte'ne Kabupaten Maros ini yaitu H. Aras yang memiliki pemikiran untuk membangun gudangnya di Daerah Perkotaan, alasannnya karena ketika membangun gudang di perkotaan maka distribusi barang yang disimpan di dalam gudangnya akan lebih muda untuk didistribusikan ke konsumen. Akan tetapi dalam perkembangannya hal tersebut tidak terealisasi karena faktor mahalnya tanah di perkotaan dan akhirnya memutuskan membangun gudangnya di Daerah Patte'ne (Aras, 2018). Hal ini didasarkan bahwa daerah tersebut dekat dengan Perkotaan dan masih tersedia banyak daerah kosong dan harganya pada saat itu masih sangat murah. Pada tahun 1995 awalnya gudang ini berfungsi untuk penyimpanan barang-barang rongsokan atau barang-barang bekas dimana gudang ini awalnya memiliki karyawan sejumlah lima orang buruh tetap dan memiliki 3 unit gudang. Barang rongsokan atau barang-bekas ini kemudian dikirim ke Makassar untuk di Olah atau di Perbaharui

Awal mulanya gudang 99 ini dibangun dengan membeli tanah. Gudang ini dibangun sedikit demi sedikit. Dalam proses pembangunannya itu mengambil uang kredit melainkan dengan kerja keras. H.aras dipercaya dengan orang-orang yang menitipkan rumput lautnya untuk disimpan digudangnya. Rumput laut ini diperoleh dari daerah pangkep dan maros baru. Gudang 99 mengeringkan dan mengemas rumput laut Selanjutnya di kirim ke 
gudang rumput laut milik Pak Romi yang ada di Desa Pa'bentengan untuk di olah.

Gudang 99 menampung barang sampai 50 ton. Gudang 99 tidak memakai CV atau PT karena harus berhubungan dengan pemerintah dikarenakan kekurangan biaya. Selama berdirinya gudang tidak pernah mendapatkan kritikan dari masyarakat.

Seiring dengan perkembangan waktu berdasarkan wawancara dengan Pak H.Aras yang menyatakan bahwa daerah ini mulai dilirik oleh begitu banyak pengusaha-pengusaha baru dan pengusaha-pengusaha lama yang mulai mengembangkan dan memperluas bisnisnya akhirnya setelah dia yang memulai membangun gudang pertama, tahun demi tahun banyak gudang baru yang di bangun di Dusun Patte'ne Kabupaten Maros dan karena hal tersebut akhirnya sampai sekarang Daerah Patte'ne disebut sebagai Pattene Business Park.

Pada tahun 1996 adalah tahun dimana CV. Sumber Pangan Nusantara (Gudang dan Pabrik Kerupuk) di Dusun Patte'ne Desa Temmapadduae didirikan. Gudang ini sudah berdiri sekitar 20 tahun yang lalu. Gudang ini dari awal sampai sekarang di pimpin oleh bapak Candra Sumawi. Yang bertempat di Jalan Raya Patte'ne no.59, provinsi Sulawesi selatan dimana merupakan badan usaha dengan produk Kerupuk yang erupakan sebuah bisnis lokal dari Maros. (Sumawi, 2019)

CV. Sumber Pangan Nusantara ini memiliki tiga gudang yang memiliki fungsi yang sama yaitu sebagai tempat penyimpanan kerupuk yang memiliki luas digabung tiga gudang yaitu tiga hektar.

Pada awal pembangunannya hanya menjadi gudang biasa menyimpan produk-produk hasil produksi kemudian tahun demi tahun dapat memproduksi sendiri produk-produk yang di simpan pada gudangnya. Gudang ini didirikan oleh Bapak Candra Sumawi yang membeli tanah dari masyarakat setempat seharga Rp.75.000/M dan hanya memiliki karyawan sejumlah 30 orang buruh akan tetapi dari tahun ketahun jumlah karyawannya itu sudah bertambah, tercatat bahwa saat ini jumlah karyawannya itu sudah ratusan orang. Karyawan bekerja full time yaitu 24 jam dan para karyawan bekerja secara shift. Gudang ini berfungsi untuk menyimpan kerupuk yang sudah dikemas dan selanjutnya di kirim ke daerah Sulawesi Selatan seperti, Makassar, Enrekang, Gowa, Pare-pare dan Palopo dan di luar Sulawesi Selatan seperti Depok, Gorontalo dan Papua.

Asal karyawan dari gudang SPN ini berasal dari Dusun Pattene atau daerah sekitar pergudangan, Maros Kota bahkan ada yang berasal dari daerah luar Kabupaten Maros. Karyawan yang berasal dari luar kabupaten Maros mendapatkan Informasi dari Keluarga yang berada di sekitar gudang atau kerabat yang berkerja di Gudang SPN tersebut. Hubungan Gudang SPN dengan pemerintah yaitu pada hal administrasi gudang misalnya pengurusan surat izin gudang.

Perkembangan gudang tidak terlalu signifikan dilihat dari penjualan dan produksinya yang dulunya enceran seharga $R p$. 500 sekarang hanya naik sekitaran Rp. 1000, bahan baku pembuatan kerupuk biasanya di peroleh dari hasil bumi lokal maupun dari pulau jawa. Perkembangan gudang ini tidak terlalu mencolok dari tahun ke tahun karena harga bahan baku mengalami kenaikan serta serta gaji karyawan yang semakin tinggi atau naik.

Pada Tahun 1997 berdiri Pergudangan bernama PT. Ekasari Lestari (Gudang Garam). Pendiri dari gudang ini adalah pak sunaryo yang ide pembangunannya dari dirinya sendiri yang melihat potensi daerah ini yang strategis. Area tempat pembangunan gudang di beli dari tanah warga yang masih kosong. Pada awalnya gudang ini tidak sebesar sekarang tetapi karena ketekunan menjalankan bisnis tersebut akhirnya bisa berkembang menjadi perusahaan yang dapat mempekerjakan puluhan orang. Pergudangan ini menyimpan produk garam yaitu garam halus dan kasar. Untuk kendala yang di hadapi oleh pergudangan ini adalah pemasukan bahan baku. Karena gudang ini tidak hanya menyimpan garam tetapi juga memproduksinya.

Garam di peroleh dari petani lalu di ambil dan di masukkan dalam karung, kemudian di pabrik di perusahaan PT. Ekasari Lestari. di gudang ini diberikan yodium dan dilakukan pembersihan lagi agar lebih baik kualitasnya. Selama beroperasi, gudang ini tidak pernah memicu konflik dengan masyarakat, dalam segi 
jumlah pekerja, gudang ini mempekerjakan 30 orang admin dan 40 orang produksi. Keterangan diatas berdasarkan wawancara dengan Ibu Rusdiana. (Rosdiana, 2019) Perkembangan perusahaan pergudangan di Daerah Patte'ne pada periode ini mengalami penurunan saat terjadi krisis moneter di Indonesia sekitar tahun 1997-1998. Krisis moneter yang melanda Indonesia mengakibatkan terjadinya inflasi keuangan sehingga berpengaruh terhadap pemasukan dan pengeluaran gudang. Tahun 1998 gudang 99, gudang CV. Sumber Pangan Nusantara dan PT. Ekasari Lestari mengurangi karyawannya tetapi gudang ini tetap memproduksi dan menyimpan barang.

\section{Perkembangan Pergudangan di Dusun Patte'ne Desa Temmapadduae Kabupaten Maros tahun 1999-2017}

Pada tahun 1999 Gudang 99, CV. Sumber Pangan Nusantara dan PT.Ekasari Lestari kembali normal dan menambah Karyawannya. Kemudian pada tahun 2000 gudang 99 beralih fungsi menjadi gudang penyimpanan Rumput laut kemudian gudang ini melakukan proses pengeringan dan pembungkusan rumput laut kemudian di kirim ke Ujung Bulo Desa Pa'bentengan Kabupaten Maros untuk dikelolah.

Setelah pulihnya krisis moneter dan krisis ekonomi selain gudang 99, CV. Sumber Pangan Nusantara dan PT. Ekasari Lestari kembali bergelia baik hasil industri maupun barang barang yang diimpor yang kemudian datang dari pulau jawa dan daerah lain sehingga membutuhkan gudang. kemudian muncul beberapa gudang di Dusun Patte'ne Desa Temmapadduae Kabupaten Maros.

Pada tahun 2006 Gudang yang didirikan oleh Pak Prengki Wijaya yang berasal dari Gowa dimana gudang ini beroperasi sebagai tempat menerima bahan jadi laksa dari beberapa daerah di Surabaya yang kemudian digudang ini di kemas dan di pasarkan ke daerah-daerah di Sulawesi Selatan. Awal pembangunan gudang ini telah memiliki ijin lengkap dari Pemerintah. Gudang laksa ini adalah salah satu perusahaan lokal di SulawesiSelatan. Lokasi gudang laksa merupakan sawah dan empang akan tetapi kemudian dibangun dan menjadi sebuah perusahaan lokal penyimpanan laksa Suriani.( A., \& Ridha, M. R. (2016),. (Martin, 2019)

Awalnya gudang ini memiliki karyawan 100 orang buruh yang berasal dari beberapa Desa di
Kabupaten Maros misalnya Desa Temmapadduae, Desa Pa'bentengan dan Desa A'bulo Sibatang. Laksa yang telah di bungkus ini kemudian di sebarkan ke Seluruh daerah daerah yang berada di Sulawesi-Selatan. Akan tetapi tingkat minat daya beli masyarakat terhadap laksa tidak seperti dengan Indomie Instan, Laksa hanya berlaku saat ada pesta besar seperti acara-acara adat dan acara pesta penikahan.

Pada tahun 2006 juga didirikan gudang kancing dimana pendirinya adalah bapak Aji Idam Rafid perusahaan ini di beri nama CV dan tahun 2007 sudah termasuk dalam PT. bahan baku di ambil diri Tufal, Donggala dan Gorontalo. Dan ketika sudah jadi, langsung di eksport ke luar negeri seperti eropa, dan Cina. (Rudi, 2019)

Awalnya PT. Cahaya Baru Madani atau Gudang kancing ini dibangun di atas tanah milik masyarakat setempat. Alasanya membangun gudang di Dusun Patte'ne Desa Temmapadduae karena tempat ini salah satu tempat yang strategis dan memungkinkan untuk pembangunan gudang.

Pada tahun 2014 muncul pengusaha baru yang bernama Renald Gozali, yang membebaskan sebagian tanah atau membeli tanah yang berada di daerah pattene. Kemudian Pak Renald membangun beberapa gudang dan menjual serta menyewakan kepada teman-temannya yang ingin mengembangkan usahanya di pergudangan tersebut. Di gudang yang dibangun Pak Renald telah mempunyai surat izin dari pemerintah.

Otonomi harus dipandang sebagai peluang untuk keberdayaan masyarakat. Pemerintah daerah sebaiknya menjadikan momen ini sebagai peluang untuk dapat memperkuat jaringan dan dapat mengintegrasikan seluruh jaringan dan kelompok sosial yang ada dalam masyarakat kedalam suatu wujud kerja sama yang saling menguntungkan (simbiosis mutualisme). Idealnya pemerintah dan kelompok sosial dalam masyarakat secara teratur berinteraksi untuk mendapatkan kesesuaian dalam melaksanakan pembangunan. Pembangunan harus dipandang sebagai proses yang memungkinkan anggota masyarakat meningkatkan kapasitas personal dan institusional dalam memobilisasi dan mengelola sumber daya untuk menghasilkan perbaikan kualitas yang sesuai dengan aspirasi mereka 
sendiri, berkelanjutan, adil dan merata. (Thamrin, 2016)

Selain tanah yang tersedia untuk bangunan gudang ini, peningkatan otonomi dan kesejahteraan masyarakat di Dusun Patte'ne adalah salah satu alasan didirikannya perusahaan, dimana penduduk mayoritas berprofesi sebagai petani. (Reza, 2010)Latar belakang pembangunan gudang di kawasan pergudangan ini bervariasi, ini dikarenakan jumlah pergudangan di daerah ini berjumlah puluhan gudang yang setiap gudang dikawasan tersebut memiliki pemilik yang berbeda-beda.

\section{a. Strategi Pemasaran Gudang}

Pemasaran menurut American Marketing Association adalah proses perencanaan dan pelaksanaan rencana penetapan harga, promosi, dan distribusi ide-ide, barang-barang dan jasa untuk menciptakan pertukaran yang memuaskan tujuan-tujuan individual dan organisasi. (Anoraga, 1997)

Demi tercapainya tujuan perusahaan, masing-masing perusahaan perlu menyadari faktor-faktor yang menentukan keberhasilan dan kegagalan dalam perjalanannya terhadap persaingan bisnis. Faktor-faktor tersebut bisa bersumber dari dalam perusahaan (interen) ataupun dari luar perusahaan (exteren). Dalam menyusun strategi pemasaran hendaknya memperhatikan lingkungan pemasaran. Lingkungan internal meliputi sumber daya yang dimiliki oleh masing-masing perusahaan baik dari kemampuan sumber daya manusia, peralatan mesin, kebijakan perusahaan dan sebagainya. Lingkungan eksternal mencakup kondisi konsumen, kebijakan pemerintah, persaingan antar perusahaan. Lingkunganlingkungan tersebut secara berangsur akan selalu mengalami perubahan, sehingga perusahaan harus dapat mengambil sikap dari setiap perubahan pada elemen lingkungannya. (Asri, 1991)

Strategi direncanakan atas dasar tujuan yang hendak dicapai sehingga dalam mencapai sebuah tujuan strategi memberikan sebuah gambaran bagaimana mencapai tujuan tersebut. Perusahaan didirikan pasti memiliki tujuan dan proses yang berbeda walaupun secara dasar tujuan setiap perusahaan adalah sama, yaitu sama-sama berusaha untuk menghasilkan laba atau keuntungan yang maksimal dari adanya pertukaran barang ataupun jasa perusahaan.

Apabila tujuan perusahaan ialah untuk menghasilkan keuntungan yang maksimal tersebut maka tujuan dari kegiatan pemasaran perusahaan adalah untuk membuat penjualan berlebihan dengan jalan memahami konsumen dengan sebaik-baiknya sehingga produsen mampu menghasilkan produk atau jasa yang sesuai dan terjual dengan sendirinya. (Philip Kotler, 1997)

Berdirinya gudang menunjukan bahwa ada beberapa strategi pemasaran yang perlu mereka lakukan untuk meningkatkan pemasaran gudang. Ada beberapa Startegi yang dilakukan oleh masing- masih gudang yang berada di Dusun Patte'ne Desa Temmapadduae Kabupaten Maros yaitu.

\section{b. Konsumen yang Ditinjau}

Usaha-usaha pemasaran akan lebih berhasil jika ditujukan kepada konsumen tertentu dan bukannya masyarakat secara keseluruhan. Konsumen yang dituju merupakan individuindividu yang harus dilayani oleh perusahaan dengan memuaskan. (Basu Swastha, 2000)

Gudang 99 dimana merupakan gudang penyimpanan rumput laut memiliki konsumen yang tinggi di Daerah Sulawesi-Selatan khusunya di maros. Maros merupakan Daerah dataran tinggi yang dekat dengan kota tempat pengelolahan rumput laut dari beberapa daerah.

CV. Sumber Pangan Nusantara yang merupakan Gudang Krupuk, Gudang Laksa, PT Cahaya Baru Madani serta CV. Makida Tunggal Perkasa masing-masing memiliki konsumen dimana membutuhkan tempat penyimpanan barang tersebut. Strategi pemasaran membutuhkan pengetahuan tentang konsumen yang ditinjau terhadap manfaat barang. Dan perusahaan-perusahaan diatas telah mempertimbangkan konsumennya dan apa yang diinginkan konsumennya sehingga dengan begitu akan dapat menekan angka kegagalan terjualnya produk Pasaran.

\section{c. Bauran Pemasaran}

Bauran pemasaran merupakan seperangkat alat yang dapat digunakan pemasar untuk membentuk karakteristik barang atau jasa yang ditawarkan kepada pelanggan. Jerome McCarthy dalam Fandy Tjiptono merumuskan bauran pemasaran menjadi 4P (Product, Price, Promotion dan Place), adapun bauran pemasaran tersebut adalah:

\section{1) Produk}

Produk merupakan segalah sesuatu yang dapat ditawarkan ke suatu pasar untuk memenuhi keinginan dan kebutuhan . (Kotler, 1998) 


\section{2) Price}

Mengacu pada harga produk tersebut agar konsumen rela mengorbankan uangnya untuk membeli produk tersebut. Hal ini juga mencakup strategi penetuan harga produk tersebut agar bisa bersaing dengan produk competitor. (Nurmayanti, N., Patahuddin, P., \& Ridha, M. R. (2019).

\section{3) Promotion}

Merupakan konsep bauran pemasaran yang terakhir, mengacu pada cara mempromosikan produk tersebut agar diterima konsumen dan melakukan pembelian. Promotion juga mencakup iklan dan publisitas. Jadi gudang yang berada di Pattene kemudian melakukan penawaran jasa penitipin kepada pengusaha yang memerlukan tempat penyimpanan barang. a. Place

Mengacu pada tempat produk tersebut dipasarkan, bagimana produk tersebut memenuhi kebutuhan konsumen agar tempatnya bisadijakau konsumen.

4) Distribusi

Menyangkut cara penyampaian produk ke tangan konsumen dapat disimpulkan bahwa perusahaan mempertimbangkan kapan dan dimana produk tersebut bisa diperoleh oleh konsumen ketika konsumen membutuhkannya. Perusahaan berusaha mendekatkan produknya dan mempermudah konsumen dalam memperoleh produk sebagai pamuas kebutuhannya kapan saja dibutuhkan.

Distribusi pada perusahaan pergudangan yang ada di dusun patte'ne ini mendristribusikan barangnya sampai ke luar Sulawesi bahkan sampai ke luar negeri. Misalnya gudang PT. Cahaya Baru Madani yang megekspor barangnya sampai keluar negeri misalnya Cina sedangkan CV. Sumber Pangan Nusantara mendistribusikan barang sampai ke luar Sulawesi seperti Gorong Tallo.

5) Estimasi waktu penyimpanan barang di pergudangan

Sebagaimana kita ketahui, gudang berfungsi sebagai tempat penyimpanan baik itu dalam skala kecil dan skala besar. Untuk perusahaan-perusahaan tentunya memerlukan tempat penyimpanan hasil produksi. Di mana hasil produksi itu bisa di ambil kapan saja. Bukan hanya sebagai tempat penyimpanan hasil produksi tetapi berfungsi sebagai tempat penyimpanan bahan mentah. Seperti PT. Sumber Pangan Nusantara yang biasanya menyimpan barang setiap 1-4 bulan sekali yang kemudian barang dikelola atau menyebarkan hasil produksi ke daerah-daerah lain.

\section{E. Kesimpulan}

Dampak kehadiran pergudangan di Dusun Patte'ne Desa Temmapadduae Kabupaten Maros ditinjau dari segi pemerintahan telah memberikan pendapatan kepada APBD Kabupaten Maros khususnya dalam hal Perpajakan. Pergudangan di Dusun Patte'ne ini masih memberikan pendapat bagi pemerintah setempat selain itu juga memberikan pendapatan bagi Masyarakat di Maros maupun dari luar maros. Meningkatnya pendapatan masyarakat akan tetapi juga memberikan dampak khusunya pada polusi udara atau pencemaran udara yang terjadi akibat adanya limbah pabrik dan asap.

\section{Daftar Pustaka}

Ahmadin., 2013. 2013. Metode Penelitian Sosial. Makassar: Rayhan Intermedia.

Akhmad., D., 2006. Managemen Pergudangan dan Persediaa. Bandung: Training WAREHOUSE.

Amirullah, A. (2017, February). Pentingnya Sejarah Dalam Pembinaan Karakter Bangsa Dan Pembangunan Nasional. In Prosiding Seminar Nasional Himpunan Sarjana Ilmu-ilmu Sosial (Vol. 2, pp. 141-148).

Anita, S. d., 2015. Pengantar Bisnis Konsep, Strategi, dan Kasus. Jakarta: PT. Buku Seru.

Anoraga, P., 1997. Management Bisnis. Jakarta: Rineke Cipta.

Aras, H., 2018. Wawancara dengan Pemilik Pergudangan Pertama di desa Desa Patte'ne [Interview] (November 2018).

Aras, H., 2018. wawancara dengan pemilik pergudangan pertama di desa pattene kabupaten Maros. [Interview] (November 2018).

Asri, M., 1991. Marketing Yogyakarta: UPP AMP YKPN.

Basu Swastha, 2000. Manajemen Pemasaran Modern. Yogyakrta: Libertty.

Kotler, P., 1998. Managemen Pemasaran Jilid Kedua. Jakarta: Prenhallindo.

Madjid, M. S., 2008. Pengantar ilmu sejarah. Makassar: Rayhan Intermedia. 
Martin, 2019. Wawancara [Interview] (Juli 2019).

Nurmayanti, N., Patahuddin, P., \& Ridha, M. R. (2019). Industri Ico Timpo Di Cabenge Kabupaten Soppeng, 2003 2017. Jurnal Pattingalloang, 6(2), 14-23.

Philip Kotler, G. A., 1997. Prinsip-Prinsip Pemasaran. Jakarta: Erlangga.

Pornomo, 2004. Perencanaan dan Perancangan Fasilitas. Yogyakarta: Graha Ilmu.

Reza, M., 2010. Strategi Ekspansi Bisnis UIN syarif Hidayatullah melalui KUIN MART. In: Jakarta: UIN Syarif Hidayatullah Jakarta.

Rosdiana, 2019. Wawancara [Interview] (juli 2019).

Rudi, 2019. wawancara di Area Pergudangan, Jalan Patte'ne [Interview] (Juli 2019).

Sjamsuddin, H., 2012. Metodologi Sejarah. Yogyakarta: Ombak.

Sumawi, C., 2019. Wawancara [Interview] (Juli 2019).

Sumawi, C., 2019. Wawancara di Kantor Pergudangan [Interview] (Juli 2019).

Sumawi, C., 2019. Wawancara di Pergudangan Patte'ne [Interview] (Juli 2019).

Suriani, A., \& Ridha, M. R. (2016). Masyarakat Pesisir Kampung Gampangcayya Kecamatan Tallo Kota Makassar 19902010. Jurnal Pattingalloang, 3(2), 14-26.

Syarifuddin, P., 2017. Operasional Manajemen Pergudangan panduan pengelolaan Gudang.. Jakarta: Mitra Wacana Media.

Thamrin, E., 2016. Peranan Organisasi Lokal dalam Pembangunan Kesejahteraan social. s.l.:s.n.

Yurasti, 2013. Mengukur kekuatan ekspansi bisnis PT. Antan Ditinjau dari aspek kinerja keuangan. Jurnal Volume 1 nomor 3.. In: Pasuman Barat: STIE YAPPAS. 